\title{
Forest cover change analysis of dry tropical forests of Vindhyan highlands in Mirzapur district, Uttar Pradesh using satellite remote sensing and GIS
}

\author{
Laxmi Goparaju, Debadityo Sinha
}

Vindhyan Ecology and Natural History Foundation, Mirzapur, Uttar Pradesh, India Vindhya Bachao Secretariat, 36/30, Shivpuri Colony, Station Road,

Mirzapur-231001, Uttar Pradesh, India, e-mail: debadityo@gmail.com

\begin{abstract}
The present study analysed the changes taking place in land use/ land cover and forest cover using multispectral satellite remote sensing data (LANDSAT TM, 2010, and LANDSAT OLI, 2013) around the Patehra, Danti, Mirzapur and Madihan forest ranges in Mirzapur district of Uttar Pradesh, India. Satellite data was visually interpreted to delineate land use and land cover classes. Post classification comparative analysis for both time periods showed agricultural expansion, urbanization and increase in open forests drastically. Further, forest area was extracted from false colour composite (FCC) (using a mask generated from LULC map) and ten forest cover classes were delineated spectrally using digital classification technique. Area statistics were computed and compared for change analysis for the time period (2010-2013). There was a marginal increase in dense mixed forests due to plantation activities, followed by increase in open mixed forest and degraded forest. A remarkable increase in area of grassland and scrubland was also noticed. Rate of change was also quantified. Higher rate of change was observed in case of degraded, fragmented and open scrub, scrubland and grassland. Thus, the forests are getting fragmented at a very fast pace. Results obtained from satellite data analysis can be effectively utilized for monitoring the changes taking place and help in establishing better management practices to conserve these forests.
\end{abstract}

Key words: Landsat, multispectral, post classification, forest cover, biodiversity, Mirzapur, urbanization, agriculture.

\section{Introduction}

Tropical dry deciduous forests are presently the most vulnerable ecosystems of the world as they are easily subjected to habitat and biodiversity loss. They occupy one tenth of world's land in terms of area, harbor more than half of the world's biodiversity (Tilman 2000; Thomas \& Baltzer 2002). They play a vital role in determining global health, ensuring food security and regulating the biogeochemical cycles. Most importantly, they sustain food for hundreds of millions of people globally (Uma Shankar et al. 2001a; Nageshwar Rao et al. 2008). Landscape transformation is taking place rapidly wherein natural forests are converted into savannah (Tripathi \& Singh 2001). The consequences are depletion of forest cover, erosion of biodiversity but livelihood of rural residents and forest dependent communities is also affected, especially women who have to work harder to collect their basic needs of fodder and fuel wood.

A large population of rural areas still depends on the tropical forests for their livelihood because of the economically and medicinally important trees. They provide shelter to a large number of fauna and are a habitat for many herbs and shrubs of medicinal importance. Chao (2012) studied and informs that the number of forest dependent people is in the range of 1.2-1.4 billion people or just under $20 \%$ of global population. Thus, forests are vital for social well-being as well. 
Tropical forests are known for their structural organization, spatial heterogeneity and adaptation to dry climate, moisture stress and irregular rainfall. Marked seasonal variation that is phenology is observed among deciduous species (Singh \& Singh 1992; Kushwaha \& Singh 2005). The high species diversity and structural complexity of the tropics pose a tough challenge to study forest structure and dynamics.

Growing population has made these forests more susceptible to conversion to agricultural farms. The present scenario is that fragmented forest patches are embedded in a matrix of landscape dominated by agricultural lands, pastures and habitations (Franklin \& Forman 1987; Myers 1994; Cale \& Hobbs 1994; Pimm \& Raven 2000; Cruse-Sanders \& Hamrick 2004; Honnay et al. 2005). The consequences faced by forest fragmentation are ecological, demographical and genetical (Nageshwar Rao et al. 2001; Uma Shankar et al. 2001b) and also affects the nitrogen mineralization of the tropical forests (Wang et al. 2004). Wildlife habitat is destroyed because of conversion of rich biodiversity centers for human settlement and industrial expansion. This results in dwindling population of wildlife, increase in vulnerability to inbreeding depression, high infant mortality and increase in human-wildlife conflict. Further, food pyramids will be affected as changes in population of herbivore and carnivore occurs, as the herbivore prey population is regulated by the population of large predators (Duffy 2003; Goparaju et al. 2005).

Satellite remote sensing has been utilized successfully for more than four decades in India, to study the distribution of natural resources country wide. The potential of satellite remote sensing data is the availability of data at different time periods and large spatial coverage. Changes taking place on the surface environment ranging from bare rocks to tropical forest can be derived by applying statistical clustering methods to multispectral remote sensing data (Defries \& Townshend 1999). The human interaction with land and environment reflected in land use data and satellite remote sensing helps in understanding these phenomena (Hurt et al. 2001).

India is one of the megadiverse countries, harboring rich biodiversity. The forests inhabiting the country are mainly tropical and subtropical in nature. The country is divided into four major ecological zones, The Himalayas, The Vindhyas, The Eastern Ghats and the Western Ghats (Murthy et al. 2003; Singh et al. 2010). The Vindhyans, highlands consist of a series of irregular mountain chains occurring centrally between the Indo-Gangetic plains and the Narmada valley. The area occupied by the Vindhyan basin is about $1,062,000 \mathrm{~km}^{2}$ (Director General of Hydrocarbons, www.dghindia/27.aspx.org). The Vindhyans lie to the north of the Baghelkhand plateau and east of the Malwa plateau. The Bijawar-Panna hills and the east facing scarp of the Sagar plateau mark its north west border, while the south-east border is marked by Bhander and Kaimur hills (Tiwari \& Jain1989).

The forests are mainly tropical dry deciduous in this region and have been exploited for various minerals for decades and presently the threats they are facing is mainly land conversion/land diversion, illicit logging, mining, over grazing and over exploitation for economically important plant species. These factors have added to the woes of further destruction and degradation of natural resources of this region. Human disturbance and anthropogenic pressures are the vital factors responsible for conversion of natural forests of dry tropics of India into forest plantations, savannah and croplands (Tripathi et al. 1999). As observed and noted by Ramakrishna (1996), the vulnerable ecosystems of the country facing stress are in the upland areas - the Himalayas in the north and the north-eastern hills, the Aravallis in the west, the Vindhyas and the Satpura ranges in central India and the Eastern and Western Ghats in the south of the country.

The tropical forest of Mirzapur is known to be a hub of important medicinal plants (Choudhary 2010). Singh \& Narain (2009) reported 183 plant species belonging to 158 genera and 60 families in Mirzapur district alone, which are used by local tribal to treat various ailments. Rural population of villages in Mirzapur depends on the existence of these forests for food, fuel and fodder (Sinha 2011).

Intact forest/frontier forests are disappearing in this region thus accelerating biodiversity loss. As reported by Global forest cover change of 2000-2012 (Hansen et al. 2013), very few hectares of intact forest remain in Mirzapur district. Around Bahuti, Danti reserve forest, Bela and Madihan reserve forest $<5$ ha intact forest have been observed. To Indian State of Forest Report, FSI 2013, it has been reported that there is no dense forest in Mirzapur, presence of medium dense forest $\left(323 \mathrm{~km}^{2}\right)$ and open forest $(544$ $\mathrm{km}^{2}$ ) have been reported.

Tropical forests have been mapped successfully using satellite remote sensing and Geographic Information System (GIS) which is a prerequisite for any conservation plan. Various techniques were used by different researchers like visual interpretation of forest and land use in part of Vindhyan range using Landsat data at 1:250,000 scale as done by Pant et al. (1992). Digital analysis of multispectral and multiseason satellite data was utilized to study various plant communities in Vindhyan region (Jha 1990; Goparaju \& Jha 2010). Landsat TM data was used to analyse the forest cover change by Niraula (2011), in Dolakha district of Nepal for the time period (1990-2010). Spatial and temporal dynamics of dry tropical forests of Myanmar were studied by Songer (2006) using satellite remote sensing and GIS. Javed and Khan (2012) utilized visual interpretation techniques to delineate land use/land cover classes and to study the changes in forests around Singrauli coal fields of Vindhyan region. Utilizing landscape metrices land use 
and land cover change were quantified by Areendran et al. (2013) in Singrauli region of the Vindhyan highlands. Analysis of spatial and temporal changes indicates the rate of deforestation is high in this region due to mining activities.

The present study focuses on studying the changes in land use and land cover in Mirzapur district as well as changes in forest cover classes between time period 2010 and 2013 using multispectral satellite remote sensing (Landsat TM) and GIS. The study focusses around reserved forests of Patehra, Danti, Madhihan and Mirzapur range.

The objectives of the study presented in this article are:

1) To study the changes in Landuse and Land cover in Mirzapur district between 2010-2013.

2) Patterns of forest cover change in dry tropical forests of Mirzapur between 2010-2013.

3) To identify the drivers of forest cover change.

\section{The study area}

The study area is Mirzapur district of Uttar Pradesh, India. It lies between $23^{\circ} 52^{\prime}$ to $25^{\circ} 32^{\prime} \mathrm{N}$ and $82^{\circ} 07^{\prime}$ to $83^{\circ}$ $33^{\prime} \mathrm{E}$. The forests here mark the beginning of the Vindhyan range. The climate is tropical monsoonal with three distinct seasons, the summer season (March - June) is hot and dry; warm and humid rainy season (July - October), cool dry winter (November - February). The temperature in summers can reach a high of $48^{\circ} \mathrm{C}$ during June month, and a low of $6^{\circ} \mathrm{C}$ in winters is observed in the January month. Rainfall varies from 90-100 cm mostly in June - September (Singh 2007). The soil varies from loamy sand to clay. Variation in colour of soil is observed from red to yellow (Das et al. 2007).

\subsection{The flora and fauna}

The forest of this region is tropical dry deciduous forest (Champion \& Seth 1968). The forest are dominated by tree species like Shorea robusta, Boswellia serrata, Anogeissus latifolia, Terminalia arjuna, Lagerstroemia parviflora, Hardwickia binata, Acacia catechu, Butea monosperma, Ziziphus glaberrima, Diospyros melanoxylon, Pterocarpus marsupium, Holarrhena antidysenterica and Emblica officinalis.

Wild animals like Sloth Bear, Leopard, Swamp Deer, Sambhar, Black Buck, Chinkara, Monkeys, Langurs Peafowl, Bengal Monitor, Mugger Crocodile Nilgai etc. have their habitat in these forests. The hot and dry climate, thick undergrowth and fruiting trees like Diospyos melanoxylon, Ziziphus mauritina, Cassia fistula, Aegle marmelos, Buchanania lanzen and $Z$. oenophila provide food and shelter to these animals.

\section{Matherials and methods}

\subsection{Satellite data acquisition}

The details of the satellite data acquired from United States Geological Survey (USGS) Environmental Resource Observation and Science Centre (EROS) archive is seen in the given table below (Table 1) which served as the main source of data for the study. The Landsat TM imageries selected to employ to map land use/land cover and forest cover change were based on the availability of cloud free scenes from USGS archives. Winter season was chosen because the trees are in leaf on condition. Phenology plays an important role in dry tropical deciduous ecosystems. Near anniversary dates were successfully selected.

\subsection{Methodology: preprocessing}

The geo-referenced satellite data was downloaded from USGS source. The Landsat TM 5 data for the time $\left(t_{1}\right)$ 03-12-2010 was obtained in 7 layers (TIFF format), each band separate (Table 2). It was layer stacked and converted into IMG format and used further. The bands used in this case are, Near Infra-red (NIR) (4), Red (3) and green (2). The Landsat OLI for the time $\left(\mathrm{t}_{2}\right)$ 25-11-2013 was also downloaded as geo-referenced file, each band separately (Table 3). Further, various layers were stacked to produce a composite image, which was then converted into IMG format. The bands in this case were 11 and the bands used for analysis are NIR (5), Red (4), and green (3). Other details are Projection UTM, Zone 44; Spheroid, WGS 84; Datum, WGS 84. Figure 1 shows the methodology adopted for the analysis. Figure 2 shows the false color composites of the two time periods (2010 and 2013) of the study area.

\subsection{Image classification}

The ultimate aim of classifying a multispectral satellite image is to automatically categorize all pixels in an image to land cover classes or themes. The grouping is based on the idea that different features manifest different combination of Digital number (DN) based on their inherent spectral reflectance and emittance properties. There are two basic types utilized for classifying the satellite data (Lillisend \& Keifer 2004). The first being the unsupervised classification, wherein the image is subjected to spectral grouping that may have unclear meaning initially, based on various algorithms and then the analyst assigns the information with each class. It is useful for forest analysis. Supervised classification is where the analyst assigns pixels to the land cover category it most looks like. One defines information categories and analyses the spectral separability. Knowledge of field is a must in this case. It is performed in the following stages: 1) training sets, 2) selection of classifica- 
tion algorithm, 3) classification and accuracy assessment, 4) post classification smoothing.

The dataset of each year (2010 and 2013) was subjected to supervised classification to delineate land use/land cover classes. The training sets were derived based on knowledge of field and published data. Other relevant thematic maps like village location have been derived from high resolution Geo Eye data in Google Earth. The image processing software used is ERDAS Imagine version 9.0 (2005).

The training sets were given based on information of field and visual interpretation of satellite data. 4-6 training sets were given from different parts of the scene for each class and merged to form a single representative class. The function Image alarm was used to see the appropriateness and extent of the signature covered in the scene. Classification algorithm chosen was of maximum likelihood. Each dataset was then subjected to accuracy assessment. Error matrix was generated and analyzed for producer's accuracy, user's accuracy and overall accuracy. The classified dataset was subjected to post classification smoothing using ' $3 \mathrm{X} 3$ ' filter to remove noise. Area statistics were computed and analyzed for each class.

\subsection{Accuracy assessment}

For Supervised classification: It determines how well a classification has categorized various classes based on the representative training sets used. The classification accuracy was thus computed by comparing the results obtained from a digital classification to the known identity of land cover by utilizing 256 randomly generated test points (Kaya et al. 1998). Each point was checked to its respective class. Overall accuracy was then computed.

The land cover was classified into six classes for time period 2013 and seven classes for time period 2010. Visual interpretation is an important technique which assists an interpreter in getting information about land use and land cover from satellite images. Various photographic and geotechnical elements such as tone, texture, shape, size, association, drainage, landform, soil and vegetation are used to identify and delineate land use and land cover classes (Lillisend \& Keifer 2004; Javed \& Khan 2012). Further, the non-forest area mask was generated from this supervised classified data. The mask was used to extract forest area from the false colour composite of each time period. The forest area was exclusively subjected to unsupervised classification to delineate spectrally similar forest clusters. Accuracy assessment was done for each classified dataset (supervised and unsupervised) independently by generating 250 random points (ERDAS version 9.0, 2005). These points were then allotted to the concerned forest cover category after confirmation from ground truth. The accuracy of unsupervised classifications (for change analysis) was calculated as a product of the two individual accuracies (Jha \& Unni 1994).

\subsection{Rate of forest cover change}

The rate of forest cover change was assessed using the following formula of Puyravaud (2003):

$$
\mathrm{P}=\frac{1}{t_{1}-t_{2}} \ln \left(\frac{A_{2}}{A_{1}}\right)
$$

where $\mathrm{P}=$ the rate of forest cover change, $\mathrm{t}_{1}=$ time period (2010), $t_{2}$ is time period (2013).

$\mathrm{A}_{2}=$ Area for time period $\mathrm{t}_{2}$ (for a particular forest cover), $A_{1}=$ area for time period $t_{1}$ (for a particular forest cover).

\section{Results and discussion}

\subsection{Land use/land cover analysis}

Accuracy assessment (2010 and 2013): The overall accuracy of the supervised classification of (Landsat 5 TM, 2010) was $87.89 \%$, whereas for (Landsat OLI, 2013) was $88.67 \%$. A satisfactory accuracy results indicate that training sets were homogenous, and that land cover classes were spectrally separable. The classification strategy chosen work efficiently for the area of interest (Lillisend \& Keifer 2004). Classification accuracy thus implies that it is an agreement between the training area pixels and ground truth information (Trietz et al. 1992). These land cover classes were quite distinct and had negligible merging of spectral signatures. A high accuracy in land cover classification using Landsat data was also observed by Chitade \& Katyar (2010), Sugumaran et al. (1994) and Mahajan et al. (2001).

Agriculture/settlement/fallow: They were observed on false color composite as areas with pink/magenta colour. They cover areas pertaining to geometrical shapes like square/rectangle etc., the area is seen to be interspersed with fallow land and settlement in between. It appears as smooth-medium texture having non-contiguous pattern with regular- sub-regular outline in shape. In 2010, it was $47,864.00$ ha under this category, which increased to $56,185.20$ ha in 2013. A net increase of $8,320.68$ ha indicates that agricultural practices have gained momentum in the past 3 years remarkably.

Fallow/urban/settlement: Such places are visible on FCC as cyan color, irregular in shape, in between urban and settlement. Urban area means developed area having building of regular shape and size, whereas settlements are scattered and irregular in shape. In 2010, an area of $47,262.15$ ha was occupied by this category, whereas in 2013 it decreased to $28,144.44$ ha. A net decrease in area is about 19,117.11 ha. This indicates that fallow land is being 


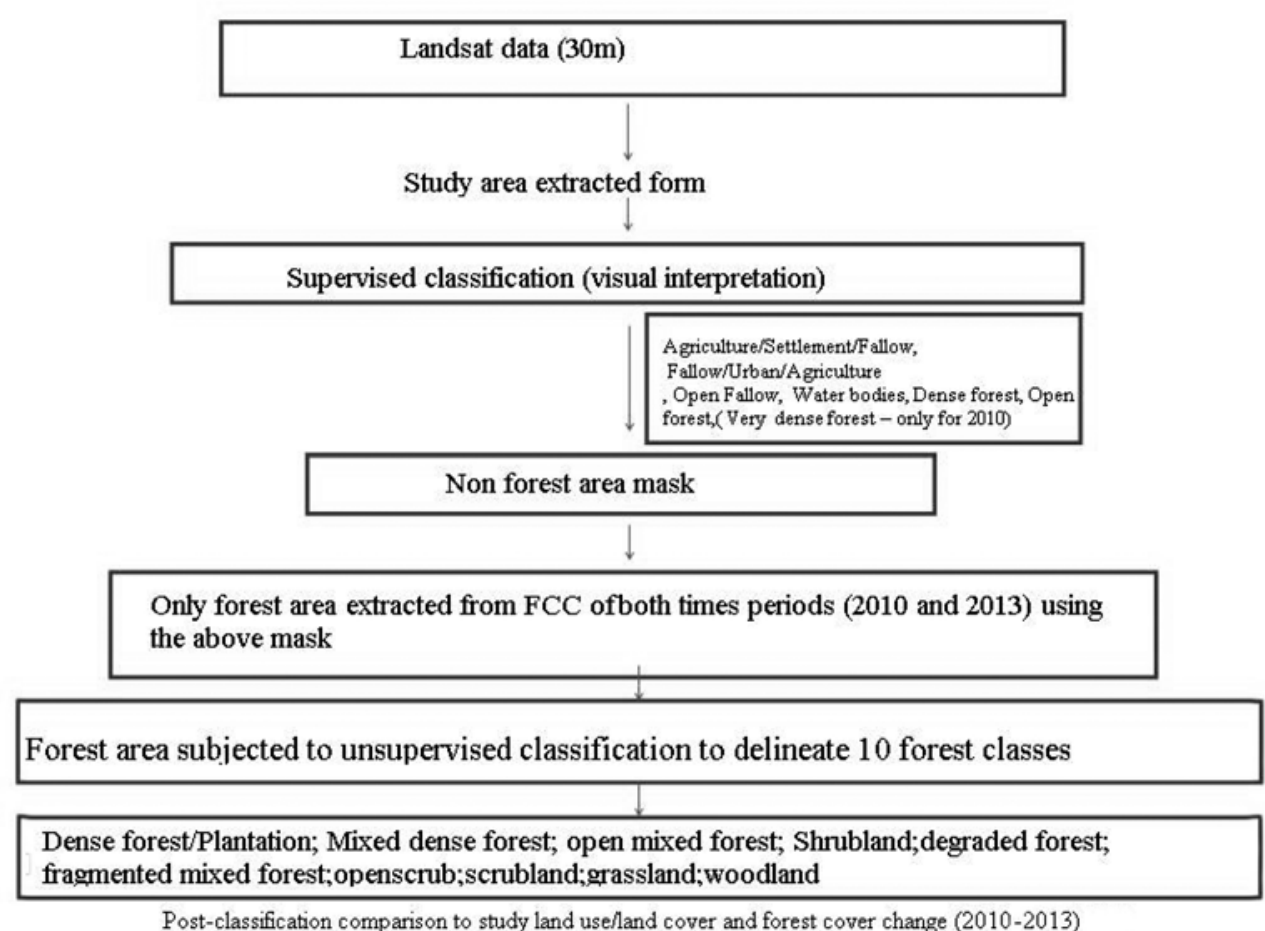

Figure 1. Flow chart explaining the methodology
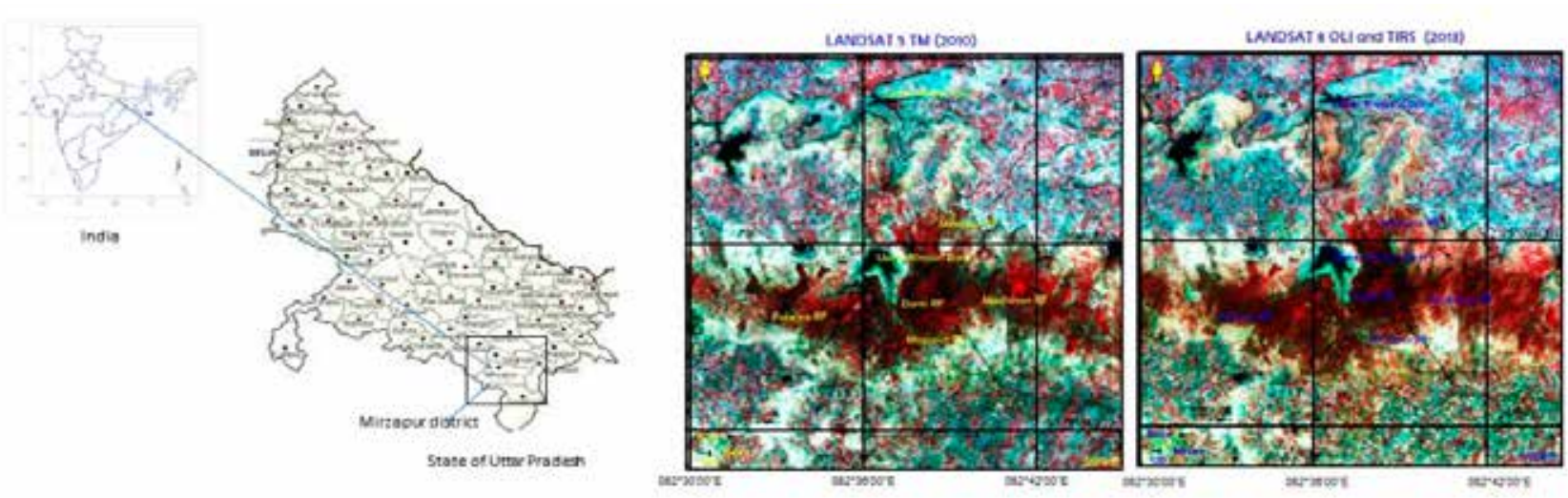

Figure 2. The location of the study area and false colour composite of both time periods

converted into agriculture, farms, orchards, settlements and also urban buildings.

Open fallow: Appears as white, grayish tone on FCC with medium to smooth texture. It is not suitable for cultivation and is irregular in shape. In 2010, the area covered in this category is $4,977.99$ ha whereas in 2013 , the area under this category decreased to $1,735.74$ ha. A difference of 3,242.25 ha in 3 years indicating that this open fallow is being utilized and converted into other land use practices.
Water: Includes all water bodies that are lakes, streams, ponds and rivers in the study area. They appear in all shades of light blue to black tone, smooth texture and irregular shape with marked tributaries and channels. In 2010 , the area occupied by water bodies that occur within the study area scene was $2,488.86$ ha, in 2013, the area was $3,926.88$ ha. It is observed in the false colour composite that the extent and area of water bodies has increased. The status of the lakes and streams has improved. 


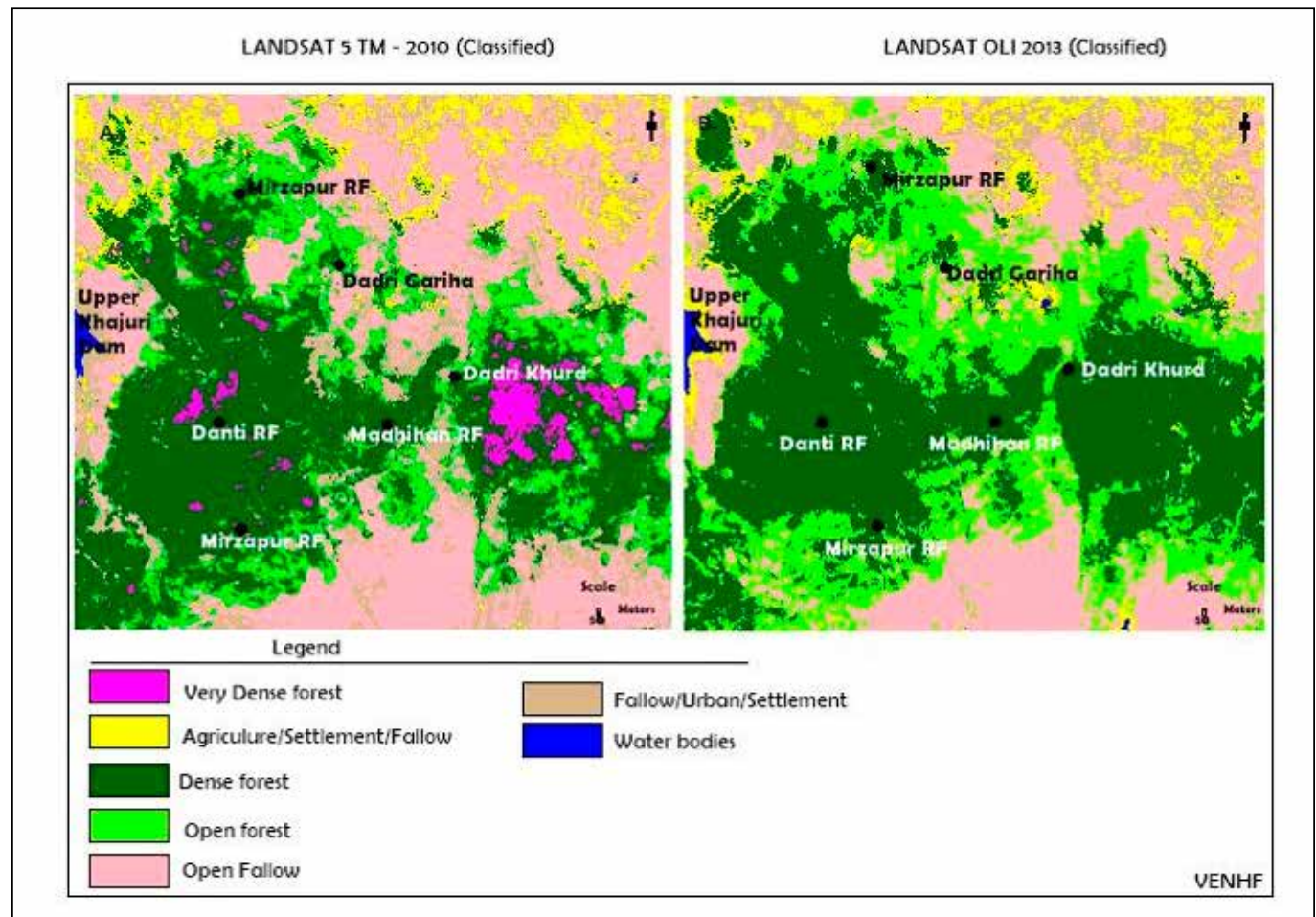

Figure 3. Land use/Land cover classes around Danti, Mirzapur and Madihan RF

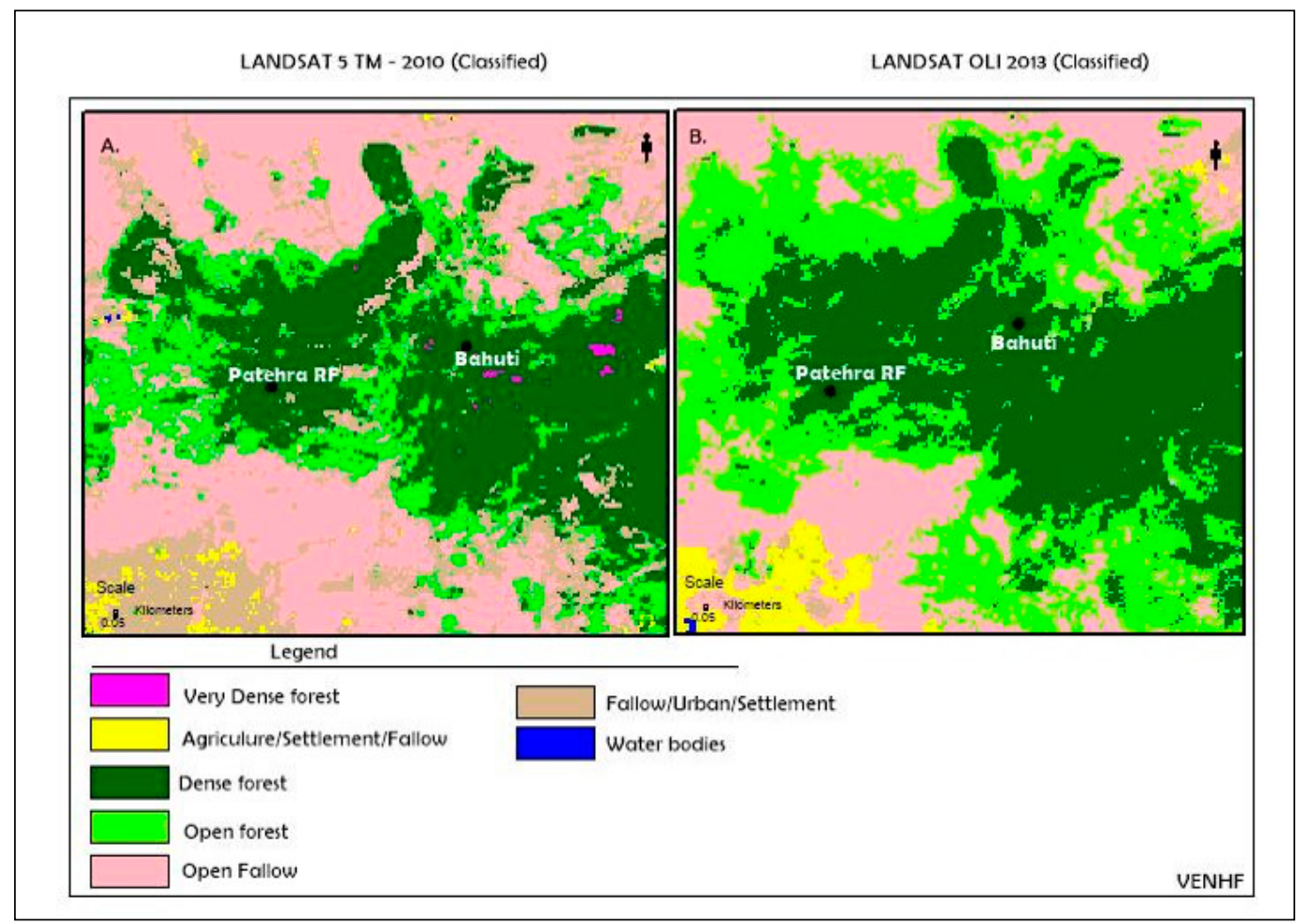

Figure 4. Land use/land cover categories around Patehra RF 


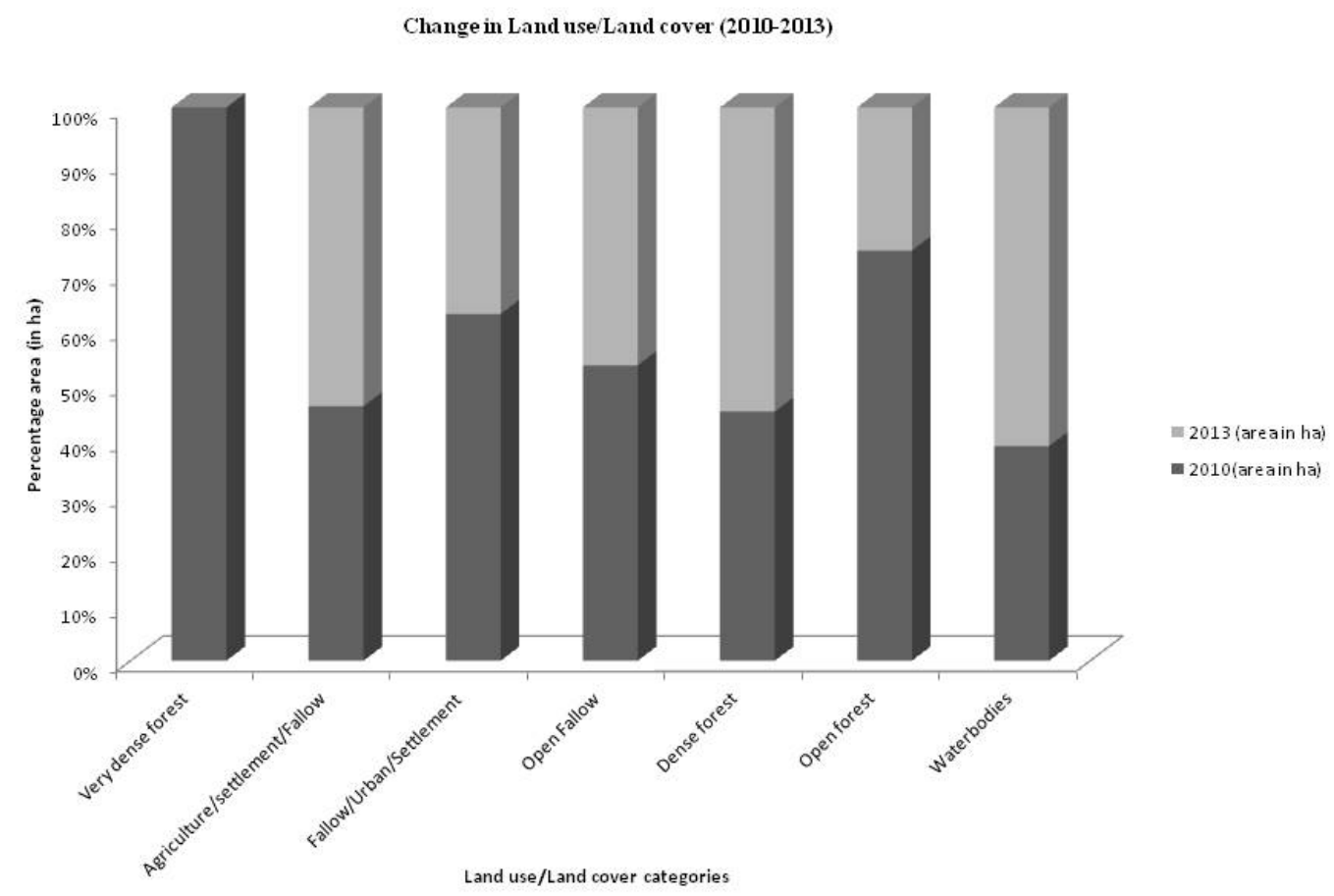

Figure 5. Graphical representation of change in percentage area (in ha) in LULC between 20102013

Dense forest: It appears as dark, red tone, coarse medium texture, contiguous pattern and regular to irregular shape. The observed canopy density is $>40 \%$. The extent of dense forest in 2010 was 12,301.92 ha whereas in 2013 it was $15,016.68$ ha. A net increase of $2,714.76$ ha can be attributed to the plantation activity taking place in this region. It occurs as large bamboo clumps interspersed with herbaceous cover.

Open forest: It appears as light red greenish color smooth medium texture, contiguous to noncontiguous pattern with irregular outline. The observed canopy density is between $10-40 \%$. The area occupied by this category in 2010 was 4,977.99 ha and in 2013 it was $1,735.74$ ha. A difference of $3,242.25$ ha indicates that open forest earlier (in 2010) if protected can transform into dense forest. Protection measures around these forests have been in practice, it seems.

Very Dense forest in (2010): This category was observed only in dataset of Landsat TM 2010. Very dense canopy of $>70 \%$ was observed. Such forests were observed to occur on plateaus, hill tops and slopes in Patehra and Madhihan forest division. In these forests the main tree species are Boswellia serrata, Pterocarpus marsupium, Cochlospermum relegiosum, Erythrina suberosa, Diospyros melanoxylon, Ficus arnottiana, Sterculia urens and Flacourtia indica.

Thus above results show that agriculture has increased much more than Dense forest (approximately 4 times the dense forest). Figure 3 showing the area around Dan- ti, Mirzapur and Madhihan reserve forest area. Figure 4 showing the land cover categories around Patehra forest. A marginal increase is seen in the case of dense forest. Decrease in open forest area has been observed. Very dense forests noted earlier in 2010 have disappeared or rather converted into dense forests (Fig. 5).

\subsection{Forest cover change analysis}

\subsubsection{Accuracy assessment and forest cover classes}

The accuracy of the unsupervised classification datasets for Landsat 5 TM (2010) was 95.50\%, and for Landsat OLI (2013) was $89.31 \%$. Thus, the accuracy for estimating the change using the two unsupervised classified datasets is $85.29 \%$ (product of the two classified datasets) (Jha \& Unni 1994).

Ten spectrally different classes were delineated in the forest category alone comprising dense and open forest. Under the dense forest the segregated classes are: 1) Dense forest/Plantation, 2) Dense mixed forest 3) Open mixed forest (transition from dense to open). Other categories which fall under the open forest category are: 1) Shrubland 2) Degraded forest 3) Fragmented mixed forest 4) Open scrub 5) Scrubland 6) Grassland 7) Woodland (Fig. 6).

Dense forest/Plantation: This usually occurrs on hill tops. The canopy cover observed is between $40-70 \%$. The major tree species occurring are Boswellia serrata and Acacia catechu. The understory is dominated by Nyctan- 


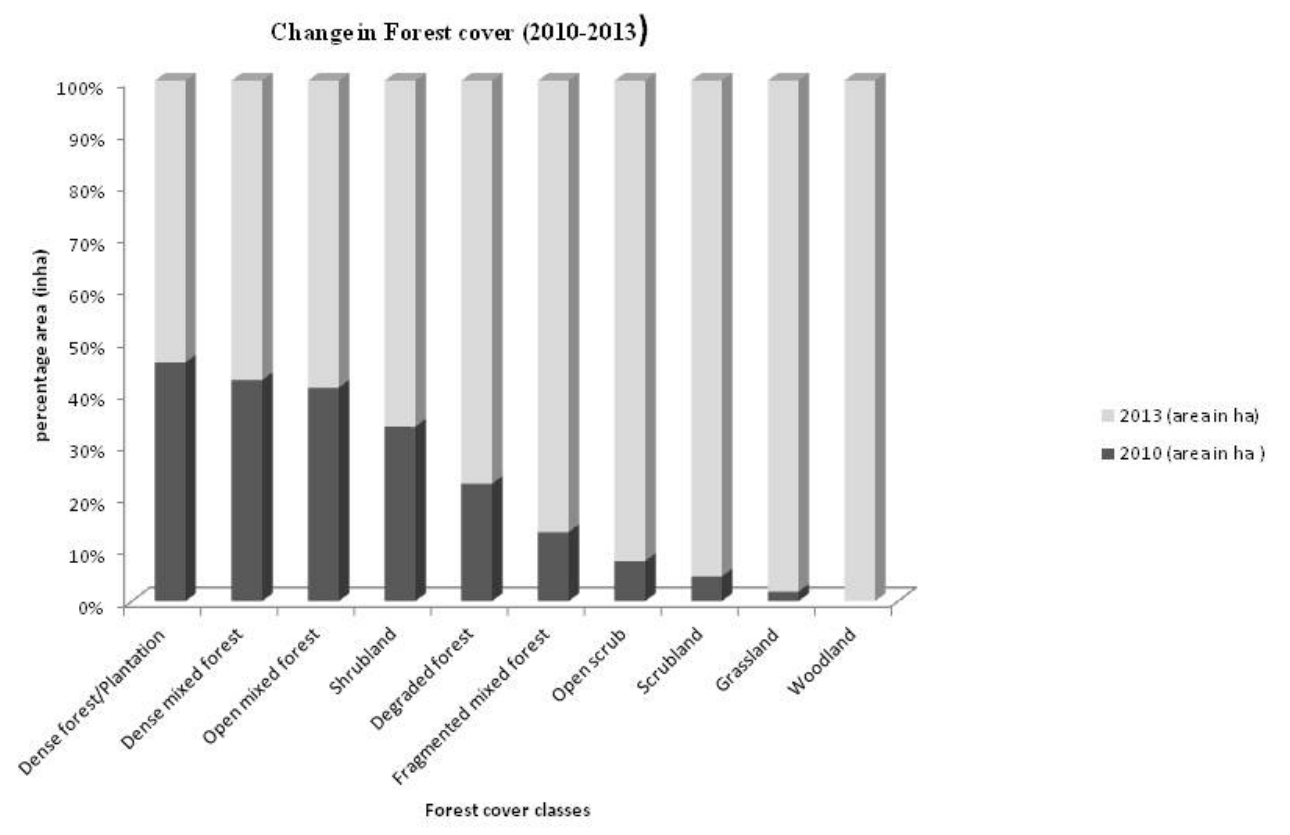

Figure 6. Graphical representation of change in percentage area of forest cover classes (2010-2013)

thes arbor-tristis, Ziziphus glaberrima. Bamboo (Dendrocalamus strictus) plantation has been undertaken by the forest department in this region since 1960's in east Mirzapur forest division (Upadhyay \& Srivasatava 1980). Figure 9 is a photograph of dense forests of Madhihan RF. Bamboo is found growing with other mixed species and occurs naturally as well. They are found on the slopes in the form of bamboo brakes, clumps are seen to occur congested. In 2010, the area covered was $4,110.48$ ha whereas in 2013 , it covered $4,849.74$ ha. The increase is marginal owing to the plantation activities; bamboo gives mixed appearance. Figure 10 shows the occurrence of bamboo in a mixed forest.

Dense mixed forest: The main species are Acacia catechu, Butea monosperma, Lagerstroemia parviflora, Anogeissus latifolia. Canopy density is between 40\%-70\%. The understory consists of Ziziphus oenophila and Acacia sinuate. In 2010, the area occupied by this cover was $5,327.01$ ha whereas in 2013 it was 7,211.25 ha. A considerable increase is seen in this category.

Open mixed forest: The canopy density is between 10-40\%. Important tree species include Acacia catechu, Butea monosperma, Lagerstroemia parviflora and Ziziphus glaberrima. The forest does not have dense canopy, in fact there are openings in between and trees occurring are far apart. In 2010, the area covered was 4,365.99 ha, whereas in 2013 , it is seen to cover 6,278.94 ha. This indicates that large openings in the forest are diminishing the canopy cover (Fig. 11).
Shrubland: It is characterized by short dense vegetation of shrubs and young trees. Tree species dominating are Butea monosperma, Ziziphus glaberrima and Acacia catechu. Large trees occur quiet far part. The lower layer in dominated by shrubs and grasses. Small trees of Ougeinia oojeinsis, Z. oenophila, Carrisa opaca are also found. They are ecologically important as they exhibit early stage in natural succession to forests, thrive well in harsh climates. They help to buffer other ecosystems and provide specialized habitats for some threatened plants and animals. In 2010, it had an area of 2,117.34 ha, whereas in 2013, it covered an area 4,200.39 ha.

Degraded forest: These mainly occupy the outer fringe of forests; all of them have mixed tree species. Canopy cover is very sparse, between $10-40 \%$. They are dominated mainly by Butea monosperma, Chrysopogon fulvus, Heteropogon contortus, Adina cordifolia, Anogeissus latifolia, Lagerstroemia parviflora and Diospyros melanoxylon, all of which occur in bushy form. Such species are exploited for their wood and leaves. It represents degraded and deformed condition of the forest. They occur along places near villages where overgrazing, illicit felling, unrestricted lopping for fuel and fodder is responsible for this status of forest. In 2010, it was 963.27 ha, whereas in 2013 it was 3,306.51 ha. A drastic increase in this category indicates that forests are degrading at a fast pace owing to the anthropogenic pressure (Fig. 12).

Fragmented mixed forest: These are the forest fragments of less than one hectare, consisting of mixed species 


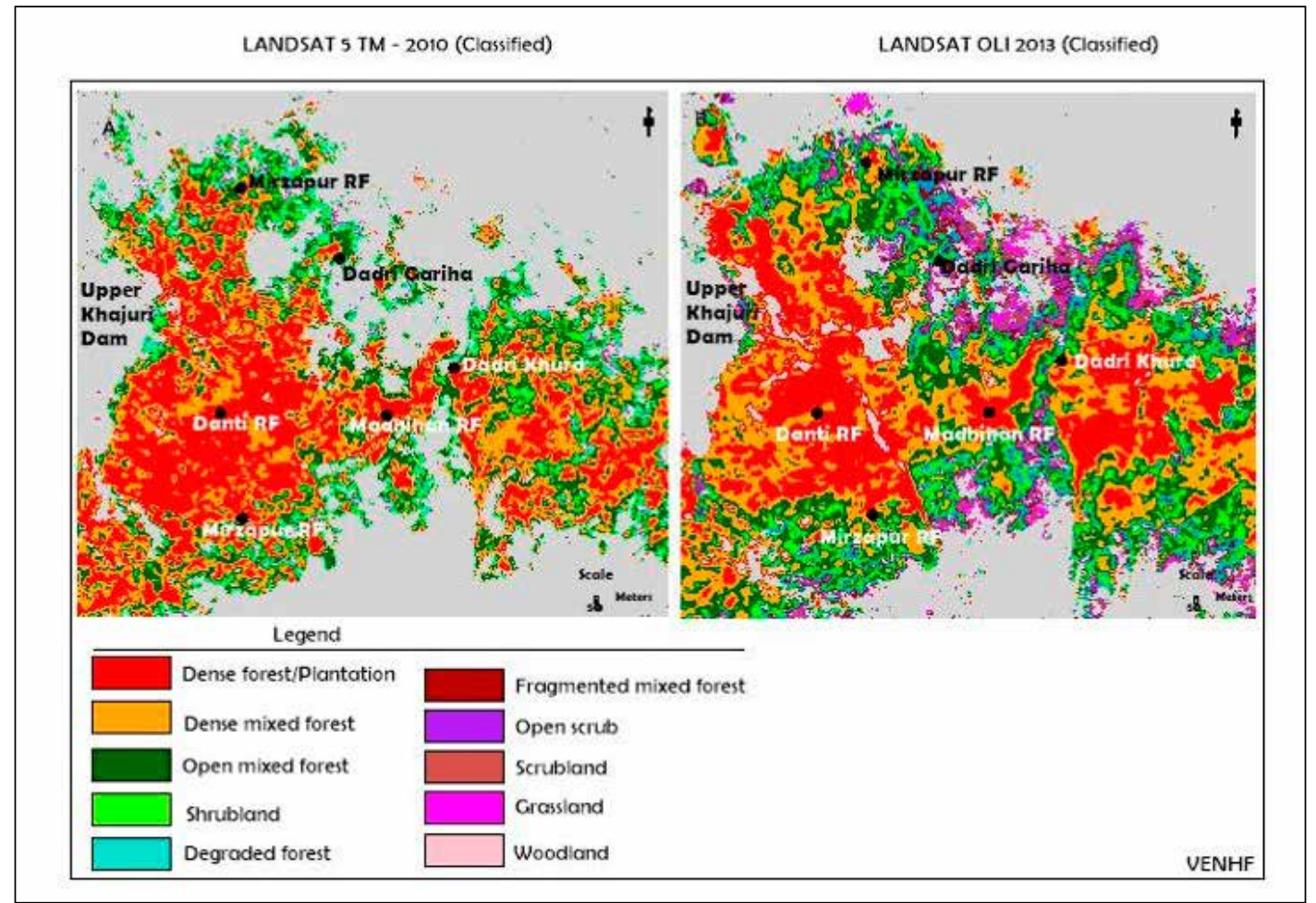

Figure 7. Forest cover classes around Danti, Mirzapur and Madihan

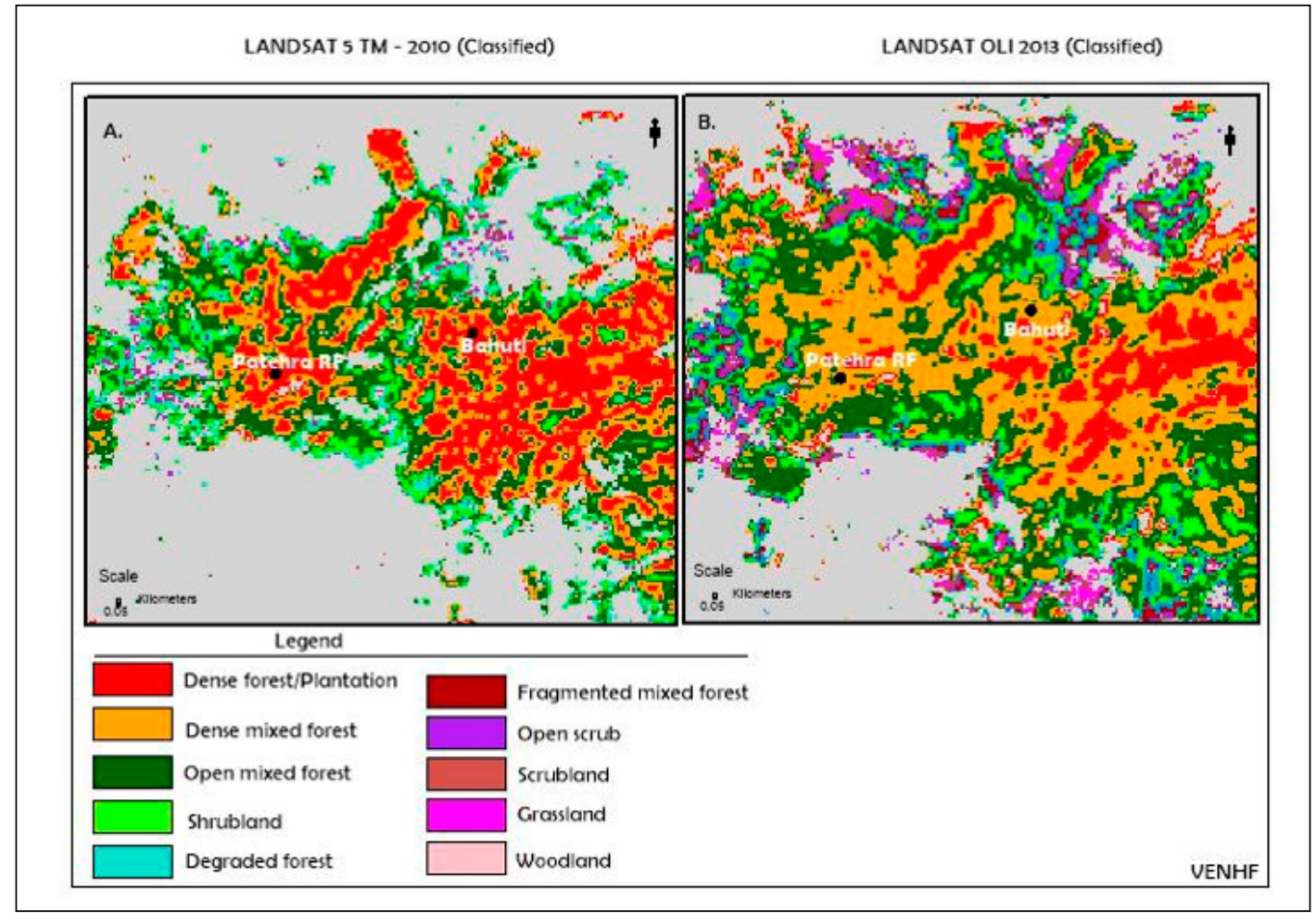

Figure 8. Forest cover classes around Patehra RF 


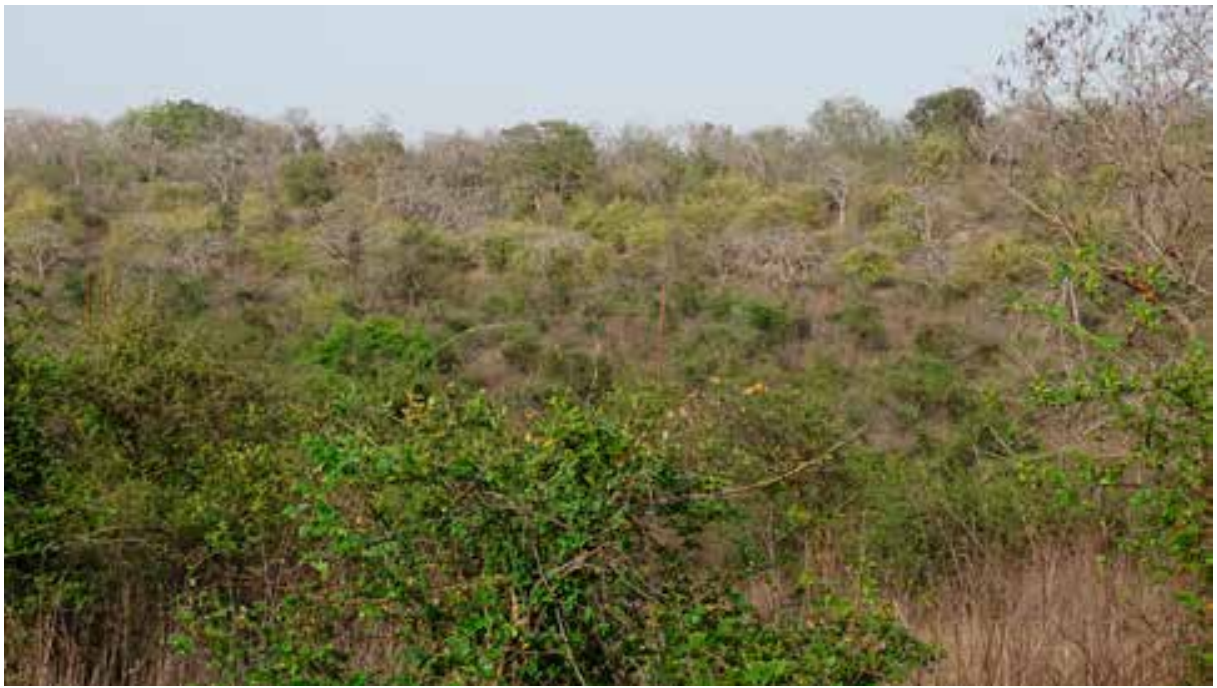

Figure 9. Dense forests of Madihan

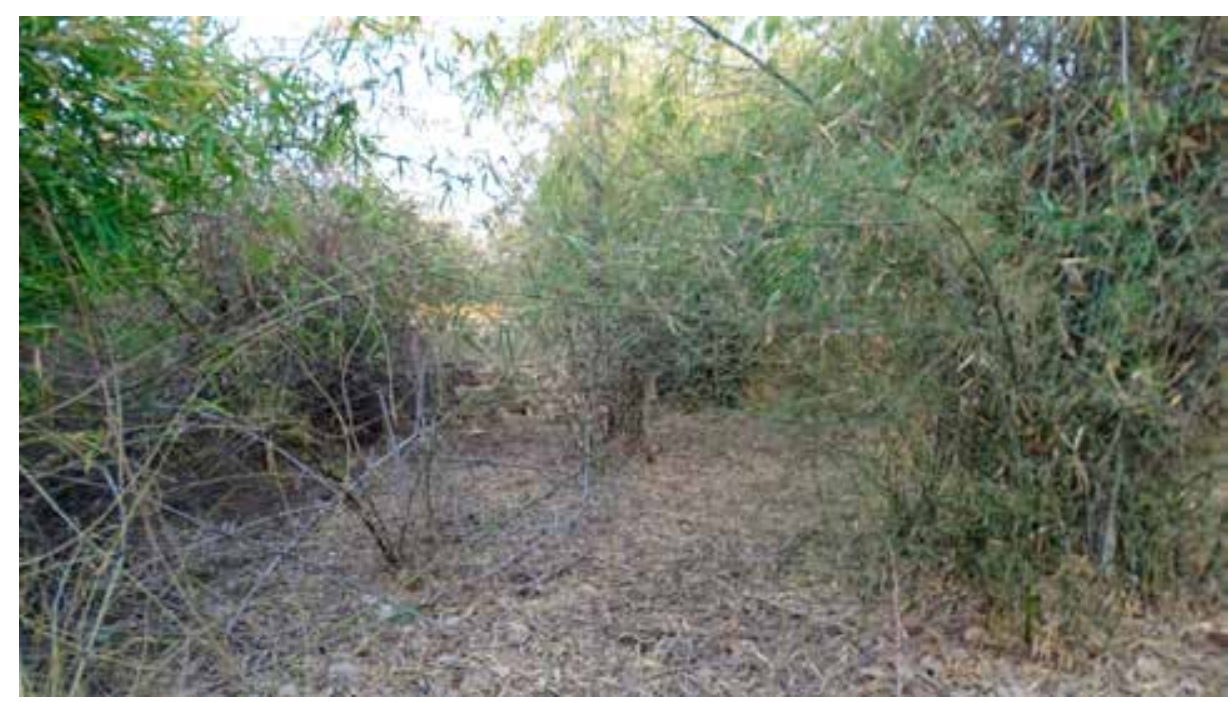

Figure 10. Bamboo occurring amidst mixed forest at Bahuti

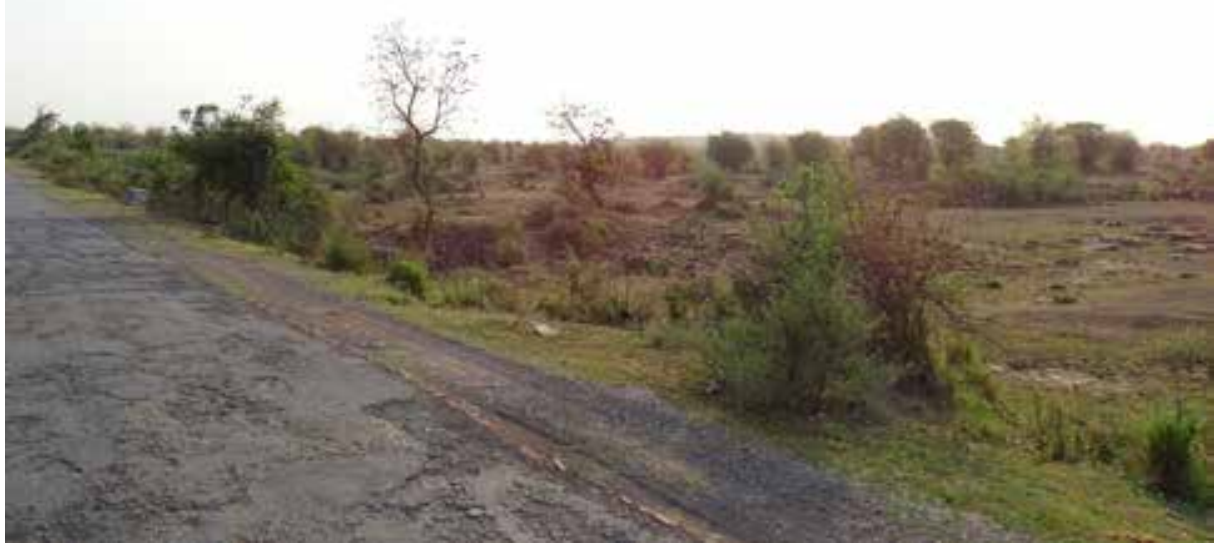

Figure 11. Dry deciduous forests near Upper Khajuri River 


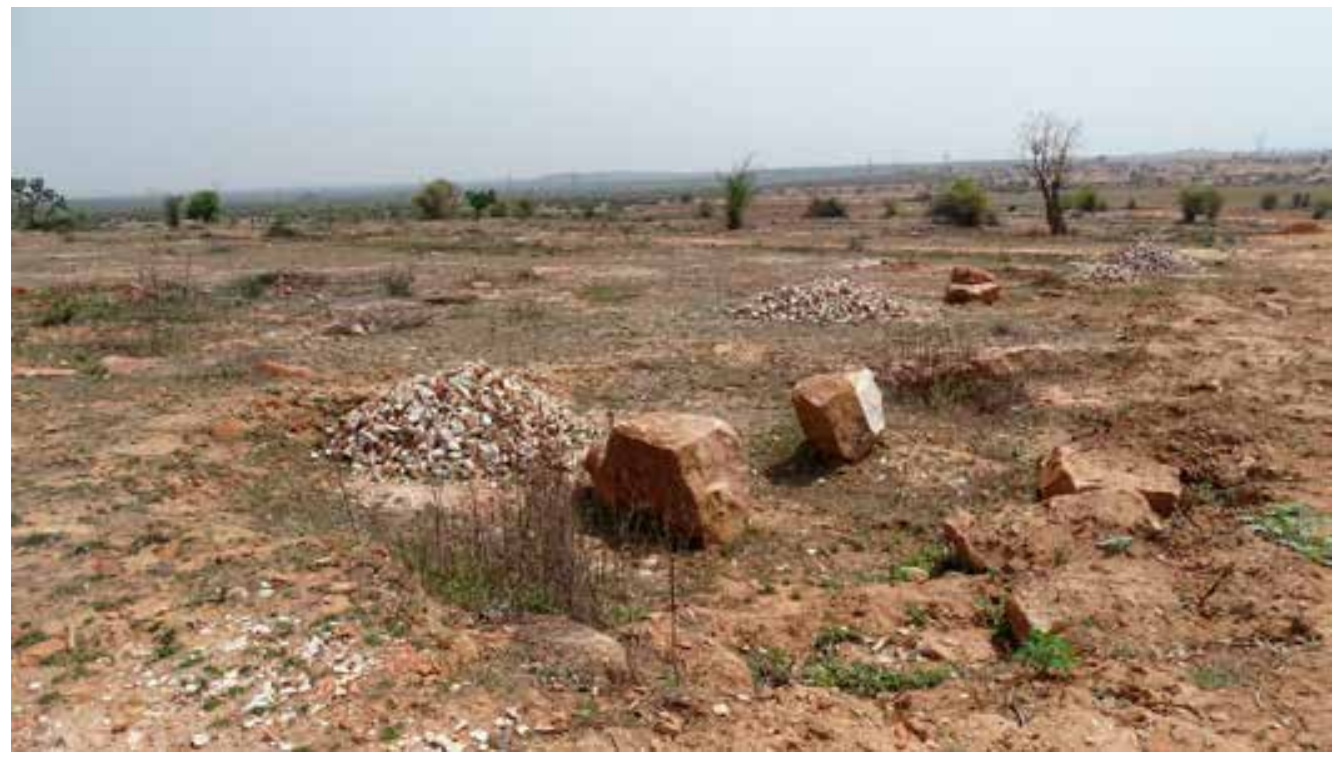

Figure 12. Encroachment at Madihan forests

mainly Acacia catechu and Butea monosperma, Ziziphus nummualria and Anogeissus latifolia. Occurrence in patches is quiet noticeable. In 2010 it occupied an area of 362.70 ha, whereas in 2013 it occupied 2,370.42 ha. A tremendous increase in this category indicates that forests are getting fragmented. Thus habitat loss is taking place for faunal species simultaneously loss of biodiversity is also inevitable.

Open scrub: It is dominated by shrubs of Ziziphus spp. and Holarrhena spp. Canopy cover is $<10 \%$. Very few large trees are seen. Increase in area of this category indicated that the forest canopy is being lost; shrubby species are gaining more importance. Still it provides a valuable habitat for animals and plants. It is has been recognized as an important element in natural succession and restoration of a mature forest. It occupied 131.67 ha in 2010, whereas in 2013, 1,580.4 ha.

Scrubland: Presence of medium-small sized trees is dominant (1-2 $\mathrm{m}$ in height). It is characterized by mild dense foliage cover. They may be naturally occurring or manmade. Sometimes they are a part of permanent mature forest. Under story of shrubs and herbs which are of medicinal importance. Grazing is the driving factor. Euphorbia scrub appears as pure forest in areas which are over grazed and have eroded soils. Trees species have less scope of natural regeneration. The area covered was 48.06 ha in 2010, in 2013 it is 965.43 ha. An drastic increase suggests that the forests are least protected.

Grassland: These are the areas dominated by grasses, shrubs and herbs. Grasses predominantly occurring are Heteropogon contortus, Saccharum spontaneum, Chrysopogon fulvus, Vetiveria zizanioides, Eulaliopsis binata,
Acacia pinata, Smilax parviflora, Asparagus racemosus and Ventilago denticulata. The area occupied was 10.62 ha in 2010 whereas in 2013, it increased up to 576.27 ha. Grasslands are capable of supporting a number of wild animals and provide habitat to them.

Woodland: It is mainly dominated by species like $\mathrm{Hol}$ arrhena antidysenterica. It is a low density forest forming open habitat with plenty of sunlight and limited shade. It supports shrubs, herbs and grasses. It is a transitional zone, may convert into shrubland if proper conservation measures taken. This category was not delineated in 2010 data due to non-availability of this spectral class, but in 2013 , it is seen to cover an area of 40.68 ha.

\subsubsection{Rate of forest cover change}

For each forest cover category rate of change was computed (Table 4). It was observed that the rate of change for dense forest/plantation; dense mixed forest and open forest was less as compared to the other categories. The higher rate of change was observed for fragmented mixed forest, open scrub, scrubland and grassland thus indicating that the forests are being converted to these categories at a fast pace.

At Danti RF, the dense forests were giving way to dense mixed forest. At Mirzapur RF, in the south it was seen that dense forests do not exist; dense mixed forests of few patches are left (Fig. 7). Increase in open forest, fragmented forests etc. was seen. But at the same time, dense mixed forest is reducing. At Patehra, dense forests are disappearing or replaced by dense mixed forest (Fig. 8). 
Table 1. Details of satellite data acquired

\begin{tabular}{|c|c|c|c|}
\hline Sensor & Bands & Path/row & Date of acquisition \\
\hline Landsat OLI & $5,4,3$ & $142 / 43$ & $25-11-2013$ \\
\hline Landsat 5 TM & $4,3,2$ & $142 / 43$ & $3-12-2010$ \\
\hline
\end{tabular}

Table 2. Details of Landsat 5 TM data

\begin{tabular}{|c|c|c|}
\hline TM Band & Resolution $[\mathrm{m}]$ & Wavelength $[\mu \mathrm{m}]$ \\
\hline 1 & 30 & $0.45-0.52$ \\
\hline 2 & 30 & $0.52-0.60$ \\
\hline 3 & 30 & $0.63-0.69$ \\
\hline 4 & 30 & $0.76-0.90$ \\
\hline 5 & 30 & $1.55-1.75$ \\
\hline 6 & 120 (resample to 30 ) & $10.41-12.50$ \\
\hline 7 & 30 & $2.08-2.35$ \\
\hline
\end{tabular}

Table 3. Details of Landsat 8 (sensors - OLI and TIRS)

\begin{tabular}{|l|c|c|c|}
\hline \multicolumn{2}{|c|}{ Landsat $8-$ spectral Band } & $\begin{array}{c}\text { Wavelength } \\
{[\mu \mathrm{m}]}\end{array}$ & Resolution [m] \\
\hline Band 1 & $\begin{array}{c}\text { Coastal / } \\
\text { aerosol }\end{array}$ & $0.43-0.45$ & 30 \\
\hline Band 2 & Blue & $0.45-0.52$ & 30 \\
\hline Band 3 & Green & $0.53-0.60$ & 30 \\
\hline Band 4 & Red & $0.63-0.68$ & 30 \\
\hline Band 5 & NIR & $0.85-0.89$ & 30 \\
\hline Band 6 & SWIR 1 & $1.56-1.66$ & 30 \\
\hline Band 7 & SWIR 2 & $2.11-2.30$ & 30 \\
\hline Band 8 & PAN & $0.50-0.68$ & 15 \\
\hline Band 9 & CIRRUS & $1.36-1.39$ & 30 \\
\hline Band 10 & TIRS & $10.60-11.20$ & $\begin{array}{c}100 \text { (resampled } \\
\text { to 30) }\end{array}$ \\
\hline Band 11 & TIRS & $11.50-12.50$ & $\begin{array}{c}100 \text { (resampled } \\
\text { to 30) }\end{array}$ \\
\hline
\end{tabular}

source: http://landsat.gsfc.nasa.gov/?p=5081
Table 4. Rate of change in forest cover classes

\begin{tabular}{|l|c|}
\hline \multicolumn{1}{|c|}{ Forest cover } & $\begin{array}{c}\text { Rate of area change } \\
{[\text { P value }]}\end{array}$ \\
\hline Dense forest/Plantation & 0.02 \\
\hline Dense mixed forest & 0.04 \\
\hline Open mixed forest & 0.05 \\
\hline Shrubland & 0.10 \\
\hline Degraded forest & 0.18 \\
\hline Fragmented mixed forest & 0.27 \\
\hline Open scrub & 0.36 \\
\hline Scrubland & 0.43 \\
\hline Grassland & 0.58 \\
\hline
\end{tabular}

\subsubsection{Drivers of forest cover change}

The results of land use/land cover classification and forest cover classification indicate that the forests are facing threat and are vulnerable to further degradation and loss.

Increase in forest cover: Plantation activities managed by the forest department have been responsible for enhancing the dense forest cover at some places. Open forest area is being lost to agriculture expansion.

Loss in forest cover: Increasing population has led to increase in urban built up areas, as simultaneously increase in agricultural activities is being observed. The fallow land as seen earlier (2010) has been used in such practices. The forests harbor economically important tree species, which are being exploited by the increasing population of the nearby villages. Besides, illegal logging is rampant for timber and non-timber produce. A large population of the surrounding settlements still depends on these forests for fuel and fodder, an issue which cannot be ignored.

\section{Approach for conservation}

An integrated approach is required for conservation. All the forest classes described above are important in terms of ecological significance. These patches of forests fall outside the protection regime and areas of wilderness to many fauna and numbers of important plant species thrive well. Dense forests are the core of the forest, undisturbed by human interventions. Such areas provide suitable habitat for wildlife. Hence such areas should be demarcated as 'No Go' zones. Infrastructure development involves felling of trees as well as paving way through the dense forests, 
which is not feasible. Degraded and fragmented forests occur along the edges of the forest boundary. Such areas are not preferred by wildlife, but since their dense habitat becomes lost they wander in such zones for food, hence these areas become hot spots for human wildlife conflict. The fragmented patches need to be protected and interconnected such that their habitat is restored. Extirpation of wildlife from small patches is more likely. The edges of these small patches should be acting as a buffer zone. The most precarious existence is that of shrublands. They face threat from land development land diversion and physical isolation. They are short lived naturally and will disappear in no time if not protected. They support number of insects, lizards and native birds. If they diminish in size so will the populations of these animals. Shrublands consist of young vegetation which is growing fast, thus will absorb more carbon from the atmosphere and will thus serve as a carbon pool. Fencing, legal protection and prevention of establishment of invasive species are the need of the hour.

Conversion of edges of forest into farmlands or agricultural plots has been noticed. Government should ensure multiple crops on limited land throughout the year. To ensure food security, protection of biodiversity is a must. The forests of this region contain a large number of economically important species. Curbing illegal exploitation of such trees should be monitored by forest officials. A balance should be maintained between proper utilization of forest resources and harvest, leading to sustainable use of forests. Patehra RF, Mirzapur RF, Madihan RF and Danti RF, should be given more protection as these adjacent small forest patches facilitate wildlife movement. This will enable connecting these patches, which are vulnerable to be separated in near future. They are the last hope and act as refugia for the last populations of endangered flora and fauna. They need attention as they mark the advent of the Vindhyan range, which form an integral part of India's social, cultural and traditional environment.

\section{Conclusion}

The present study reveals that there has been considerable land use/land cover change in the past three years. Increasing urbanization and agricultural expansion have been the main reasons and have increased pressure on the nearby reserved forests. Forests are getting fragmented and now very small forest patches are left which need protection urgently. These forest patches are a hope to save our biodiversity. This study enabled us to study the changes both spatially and temporally. The availability of free download of Landsat data further facilitates analysis in a cost effective manner. Drivers of forest cover change could be identified. Such data should be incorporated by the managers while designing forest management and conservation plans. Monitoring our forests using satellite remote sensing data coupled with field information would help us in taking appropriate decisions timely.

\section{Acknowledgement}

We thank landsat.usgs.gov, for Landsat satellite data used for analysis in the study. We also thank the Vindhya Bachao team for collecting ground truth information.

\section{References}

Areendran G., Rao P., Raj K., Mazumdar S. \& Puri K., 2013, Land use/land cover change dynamics analysis in mining areas of Singrauli district in Madhya Pradesh, India, Tropical Ecology 54(2): 239-250.

Cale P.G. \& Hobbs R.J., 1994, Landscape heterogeneity indices, problems of scale and applicability with particular reference to animal habitat description, Pacific Conservation Biology 1: 183-193.

Champion H.G. \& Seth S.K., 1968, A revised classification of the Forest Types in India, Manager publications, GOI, India, New Delhi.

Chao S., 2012, Forest peoples numbers across the world, Moreton-in-Marsh, UK, Forest people's programme (www.forestpeoples.org).

Chitade A.Z. \& Katyar K.S., 2010, Impact analysis of open cast coal mines on land use/ land cover using remote sensing and GIS technique: a case study, International Journal of Engineering Science and Technology 2(12): 7171-7176.

Choudhary R.S., 2010, Taxa of family Fabaceae: a potential of local medicinal plants in Vindhyan region, U.P., India, International Journal of Pharma and Biosciences 1(4): B46-B53.

Cruse-Sanders J.M. \& Hamrick J.L., 2004, Genetic diversity in harvested and protected populations of wild American ginseng Panax quinquefolia, Araliaceae, American Journal of Botany 91: 540-548.

Das M.K., Awasthi A.K., Pandey R., Dwivedi A. \& Koul M., 2007, Mapping of forest types and land use/land cover of Singrauli coal field area using satellite remote sensing techniques, Journal of Tropical Forestry 23: 141-150.

Defries R.S. \& Townshend J.R.G., 1999, Global land cover characterization from satellite data: from research to operational implementation?, Global Ecology and Biogeography 8: 367-379.

Director General of Hydrocarbons, under Ministry of Petroleum and Natural Gas, Government of India, www. dghindia.org/27.aspx 
Duffy J.E., 2003, Biodiversity loss, trophic skew and ecosystem functioning, Ecology Letters 6(8): 680-687.

ERDAS Imagine version 9.0, 2005, ERDAS field guide, Copywright Leica Geosystems Geospatial Imaging, LLC (1991-2005), Printed in USA.

Franklin J.F. \& Forman R.T., 1987, Creating landscape patterns by forest cutting ecological consequences and principles, Landscape Ecology 1: 5-18.

Goparaju L. \& Jha C.S., 2010, Spatial analysis of plant communities in fragmented forest of dry tropics in Vindhyan highlands using remote sensing and GIS, International Journal of Tropical Ecology 51(1): 55-65.

Goparaju L., Tripathi A., Jha C.S., 2005, Forest fragmentation impacts on phytodiversity - An analysis using remote sensing and GIS, Current Science 88: 1264-1274.

Hansen M.C., Potapov P.V., Moore R., Hancher M., Turubanova S.A., Thau D., Stehman S.V., Goetz S., Loveland T.R., Kommareddy A., Egorov A., Chini L.C.O. \& Townshend J.R.G., 2013, High resolution global maps of $21^{\text {st }}$ century forest cover change, Science 342: 850-853.

Honnay O., Jacquenmyn H., Bossuyt B. \& Hermy H., 2005 , Forest fragmentation effects on patch occupancy and population viability of herbaceous plant species, New Phytologist 166: 723-736.

http://landsat.gsfc.nasa.gov/?p=5081

Hurt G.C., Rosentrater L., Frolking S. \& Moore B., 2001, Linking remote sensing estimates of land cover and census statistics on land use to produce maps of land use of the conterminous United States, Global Biogeochemical Cycles 15: 673-685.

Javed A. \& Khan I., 2012, Landuse/Land cover change due to mining activities in Singrauli Industrial belt, Madhya Pradesh using remote sensing and GIS, Journal of Environmental Research and Development 6: 521-529.

Jha C.S., 1990, Analysis of vegetation and land use in Obra, Renukoot, Singrauli area, Ph.D. Thesis, Banaras Hindu University, Varanasi, India.

Jha C.S. \& Unni M., 1994, Digital change detection of forest conversion of a dry tropical Indian forest region, International Journal of Remote Sensing: 15: 2543-2552.

Kaya S., Musaoglu N., Ormeci C. \& Muftuoglu O., 1998, Forest damage assessment by using remote sensing data, [in:] D. Fritsch, M. Englich, N. Sester (eds) GIS Between Visions and Applications, IAPRS vol. 32/4, ISPRS commission IV symposium, Stuttgart.

Kushwaha C.P. \& Singh K.P., 2005, Diversity of leaf phenology in a tropical deciduous forest in India, Journal of Tropical Ecology 21: 47-56.

Lillisend T.M. \& Keifer R., 2004, Remote sensing Image interpretation, John Wiley, New York.

Mahajan S., Panwar P. \& Kaundal D., 2001, GIS application to determine the effect of topography on land use in Ashwani Khad watershed, Journal of Indian Society of Remote Sensing 29(4): 243-248.

Murthy M.S.R., Giriraj A. \& Dutt C.B.S., 2003, Geoinformatics for biodiversity assessment, Biological Letters .40(2): 75-100.

Myers N., 1994, Tropical forests and their species going?, [in:] G.T. Miller (ed.) Living in the Environment, International Thompson Publishing, Belmont, California, USA: 288-289.

Nageshwar Rao M., Sudarshan P., Ganeshaih K.N. \& Uma Shankar R., 2008, Impacts of human disturbances on medicinal NTFP species, Biosectrum Asia (http:/www. biospectrumasia.com/content/150908IND7092.asp).

Nageshwar Rao M., Umashankar R. \& Ganeshiah K.N., 2001, Mapping genetic diversity of sandal (Santalum album L.) in south India: Lessons for in situ conservation of sandal genetic resources, [in:] R. Uma Shankar, K.N. Ganeshiah, K.S. Bawa (eds) Forest genetic resources status, threats and conservation strategies, Oxford and IBH Publishing company private Ltd., New Delhi: 49-67.

Niraula R.R., 2011, Forest cover change analysis in Dolakha district (1999-2010) application of remote sensing and GIS, Nepal - Swiss community forestry project, SDC, Inter-cooperation, Nepal.

Pant D.N., Das K.K. \& Roy P.S., 1992, Mapping of tropical dry deciduous forest and land use in part of Vindhyan range using satellite remote sensing data, Journal of Indian Society of Remote Sensing 20: 19-20.

Pimm S.L. \& Raven P., 2000, Biodiversity extinction by numbers, Nature 403: 843-845.

Puyravaud J., 2003, Standardizing the calculation of the annual rate of deforestation, Forest Ecology and Management 177: 593-596.

Ramkrishna P.S., 1996, Biodiversity research agenda for the Asia Pacific region, [in:] I.M. Turner, C.H. Diong, S.S.L. Lim, P.K.L. Ng (eds), Biodiversity and the dynamics of Ecosystem, DIWPA series, 1: 39-50.

Singh A., 2007, Revegetation of coal mine spoils using Prosopsis juliflora in Singrauli coalfield is a harmful practice from ecological viewpoint, Current Science 93: 1204.

Singh U. \& Narain S., 2009, Ethnobotanical wealth of Mirzapur district, U.P.: 135(2): 185-197.

Singh J.S., Roy P.S., Murthy M.S.R. \& Jha C.S., 2010, Application of landscape ecology and remote sensing for assessment, monitoring and conservation of biodiversity, Journal of Indian Society for Remote Sensing (Special issue: Biodiversity and Landscape Ecology) 38: 365-385.

Singh J.S. \& Singh V.K., 1992, Phenology of seasonally dry tropical forest, Current Science 63(11): 684-689.

Sinha D., 2011, Fuelwood consumption pattern in rural Mirzapur Sources and implications, M.Sc. Disserta- 
tion, Tech in Environmental Science and Technology, Banaras Hindu University, India.

Songer M.A., 2006, Endangered dry deciduous forest of Upper Myanmar, Burma: a multiscale approach for research and conservation, Ph.D. Dissertation, University of Maryland, USA.

State of Forest report of India, 2013, Forest Survey of India. Ministry of Environment of forests, GOI, Dehradun, India.

Sugumaran R., Sandhya G., Rao K.S., Javed R.N. \& Kimothy M.M., 1994, Stratification approach for forest cover type and land use mapping using IRS 1A LISS II data - A case study, Journal of Indian Society of Remote Sensing 22(1): 21-29.

Thomas S.C. \& Baltzer J.L., 2002, Tropical forests, [in:] Encyclopedia of life sciences, Macmillan References Ltd, Nature Publishing Group, London, UK: 1-8.

Tilman D., 2000, Causes, consequences and ethics of biodiversity, Nature 405: 208-210.

Tiwari P.D. \& Jain C.K., 1989, Modernization of Agriculture and food availability in India, Northern Book Centre, New Delhi, India.

Treitz M.P., Howarth J.P. \& Gong P., 1992, Application of satellite and GIS technologies for land cover and land use mapping at the rural urban fringe: A case study, Photogrammetric Engineering and Remote Sensing 60(3): 330-337.

Tripathi S.K. \& Singh K.P., 2001, Ecological response of dry tropical forest and savanna ecosystems to nutri- ent enrichment, [in:] P.K. Jha, S.R. Baral, S.R. Karamcharya, H.D. Lehate, P. Lacoul, C.B. Baniya (eds) Environment and agriculture: Biodiversity, Agriculture and Pollution in South Asia, Publisher Ecology Society, Kathmandu, Nepal: 150-157.

Tripathi S.K., Singh K.P. \& Singh P.K., 1999, Temporal changes in spatial pattern of fine root biomass and nutrient concentration in Indian bamboo savannah, Applied Vegetation Science 2: 229-238.

Uma Shankar R., Ganeshiah K.N. \& Nageshwar Rao M., $2001 b$, Genetic diversity of medicinal plant species in deciduous forests of India: Impacts of harvesting and other anthropogenic pressures, Journal of Plant Biology 28: 91-97.

Uma Shankar R., Ganeshiah K.N. \& Nageshwar Rao M., 2001a, Conservation of genetic resources of Triphala in South India: Identifications of hot spots for in - situ conservation, [in:] Medicinal plants, a global heritage, IDRC and CRDI: 115-128.

Upadhayay M.D. \& Srivasatava S.C.N., 1980, Forest Working Plan East Mirzapur Forest Division, circle, Varanasi II from 1981-1991, State Forest Department, Nainital, U.P., India.

Wang C., Xing X. \& Han X., 2004, Advances in study factors affecting soil $\mathrm{N}$ mineralization in grassland ecosystems, The Journal of Applied Ecology 15(11): 21842188 (in Chinese). 